\title{
Transformation of the Ukrainian cities within post-Chornobyl and Post-totalitarian 'transitional' period
}

\author{
Mykola Dyomin'1, Tamara Panchenko,, Iryna Ustinova ${ }^{3}$ \\ Kyiv National University of Construction and Architecture \\ Povitroflotskyy avenue 31, Kyiv, Ukraine, 03037 \\ 1 deminmaster@gmail.com, orcid.org/0000-0002-3144-761X \\ 2 panchenko.knuba@gmail.com, orcid.org/0000-0001-6341-230X \\ ${ }^{3}$ ustinova.ii@knuba.edu.ua, orcid.org/0000-0002-1728-0200
}

Received 15.05.2021, accepted for publication 19.09.2021

https://doi.org/10.32347/tit2021.42.0101

\begin{abstract}
The study of the transformation of Ukrainian cities in the post-Chornobyl and posttotalitarian transition period highlighted a number of general development trends and regional features of the global urban process. Despite the socio-economic upheavals, Russia's military aggression and population decline, Ukraine has entered the 'human development high category' list of countries. Studies have shown that the country urbanization level continues to grow, while balancing its spatial development potential. This is evidenced by the emergence of the 'South-West Spatial Vector', the 'West Sector' and the 'Meridional Axis' of the urbanization process development. This indicates, first, the 'spatial structures memory', the presence of which allows us to interpret post-socialist transformations as a 'return to pre-socialist development trajectories' of Ukraine in common Pan-European space; secondly, on the cyclical development and reversibility of 'waves vibrational motion' of the world urban process; thirdly, the 'country urbanized space reaction' to the Russian military aggression in the East of Ukraine, the annexation of the Autonomous Republic of Crimea and part of the Donbas territories.

The specifics of the post-socialist development of the Kyiv Agglomeration reflect the new status of Kyiv and the general trend of development of the European metropolitan network, as well as the 'gravitational pattern' of spatial development, which is manifested by territorial uneven economic development and 'growth poles wave migration' from center to periphery and vice versa. The postChornobyl growth of the tourist attractiveness of
\end{abstract}

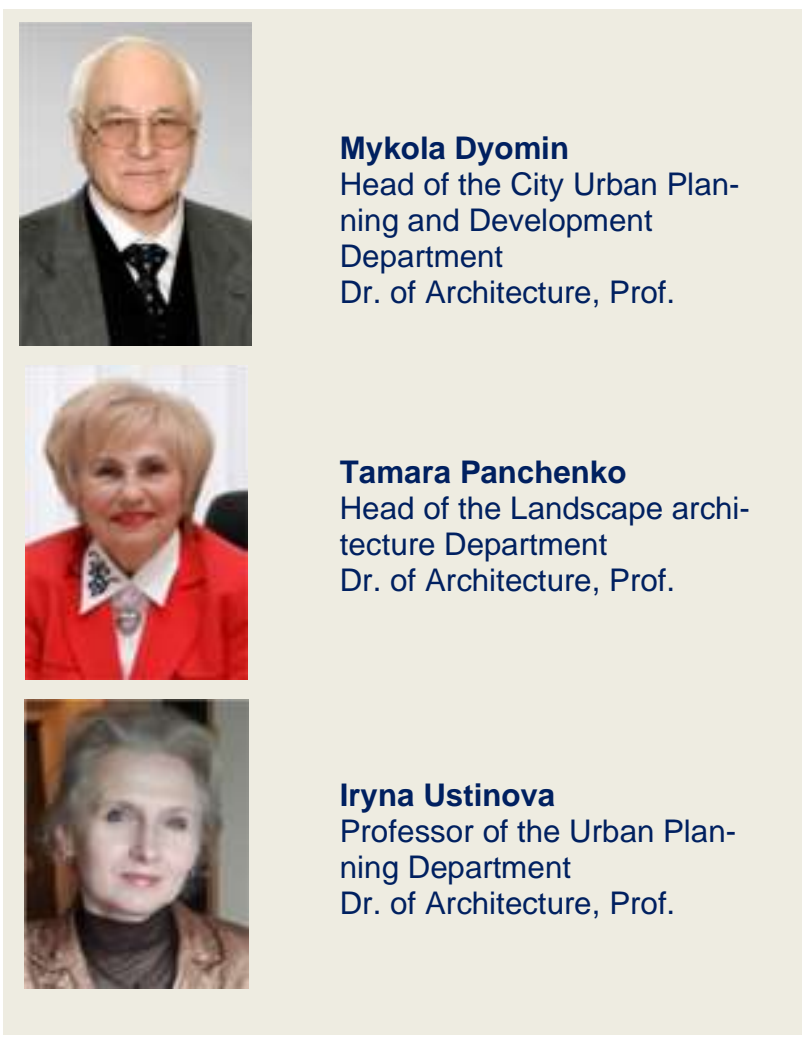

the Chornobyl Exclusion Zone, where $80 \%$ of visitors are foreigners, will contribute to the further transformation of Ukrainian cities. In particular, air communication - the development of Kyiv and the Kyiv Agglomeration; roads - development of bordering cities in the west and south of the country, as well as cities in the areas of Pan-European transport corridors influence; railway - the development of Kyiv, Chernihiv, Slavutych; the Dnipro - Visla waterway project implementation, the pur- 
pose of which is the connection of the Baltic and Black Seas - the development of city-river ports along the Dnipro and Pripyat Rivers.

Keywords: urban processes, environmental and town-planning systems, cities, settlement systems, post-totalitarian period, Chernobyl exclusion zone (area of alienation).

\section{INTRODUCTION}

35 years passed since April 26, 1986, when the Chornobyl nuclear disaster took place, which, according to the AEC (INES) International scale, was classified as the danger highest - seventh level, with the radioactive cloud covering most of Europe. Then within a 30 kilometers radius around the Chornobyl nuclear power plant more than 115 thousand of Polissya inhabitants were evacuated and more than a 2,500 sq. km territory was separated from adjacent territories and transferred to the radiation-hazardous lands category [1]. It will soon be 30 years since August 24, 1991 - the date of the declaration of independence of Ukraine. What happened to us during this period? What happened to the cities we live in?

Nowadays Ukraine adopted the Law "On the National Program of Decommissioning of the Chornobyl NPP and Shelter Transformation into an Environmentally Safe System", according to which the NPP should be liquidated by 2065. Therefore, among the topics of the great interest in the world is Chornobyl Tourism - the opportunity to visit the Chornobyl Exclusion Zone and the zone of unconditional (compulsory) resettlement for scientific and educational purposes.

The number of the Chornobyl zone visitors from 2014 to 2019 increased 15 times. According to the Center for Organizational, Technical and Information Support of Exclusion Zone Management State Enterprise' official website, 124 thousand people visited it in 2019, almost $80 \%$ of them are foreigners. Among the leading countries whose citizens visited Chornobyl: Great Britain - 18.5 thousand people, Poland - 10.4 thousand people, Germany - 9 thousand people, the United States -6.4 thousand people, the Czech Republic - 4.6 thousand people $[2,3,4]$.
Among the second 'attraction' of scientific interest in the world are the processes of urban development that are inherent in the countries that have long suffered due to communist totalitarian regimes $[5,6,7]$. Ukraine is one of these countries. In terms of population, it is the seventh (as of April 1, 2021 - 41.5 million people, excluding the temporarily occupied territory of the Autonomous Republic of Crimea) $[8,9]$, and in terms of area - the largest European country (603.6 thousand sq. km) [10]. The post-totalitarian transition period of the country's development, which began in 1991 on the post-Chornobyl background, after 2014 it was burdened by Russian military aggression - the occupation of the Autonomous Republic of Crimea and part of the territories in Donetsk and Luhansk regions.

Post-socialist transformations, as economic, political, institutional and ideological changes associated with the communism rejection in Central and Eastern Europe [5], are accompanied by complex and lengthy reconfigurations in many areas [11]. The projections of these changes in the urban space are the transformations of the country settlement system and the network of its populated cities. These changes in Ukrainian cities in the posttotalitarian transition period led to the layering in the 'globalization power field' of several identities: the past Soviet, national Ukrainian and the desired European [12].

As for political and democratic transformations, the transition period of Ukraine's development was marked by the revolutions of 2004 and 2013; reforming and decentralization of powers, with its transition to local selfgovernment and transformation of the territorial-administrative system. In the socioeconomic sphere, there was a transition from a planned economy to a market economy and privatization.

This has led to fundamental changes in the paradigm of urban planning (at least in practice): if during the socialist (Soviet) period it was the main subject of urban development, in the post-socialist period the state, being not the main subject that determines directions of urban development, belatedly responds to existing challenges [13]. 
In the demographic sphere of the country the depopulation process continues since 1993, which during the first decade occurred due to the accelerated reduction of its urban population on the background of further expansion of urban areas (Fig. 1) [14].

The environmental area of the country, based on environmental pollution problems, was marked by measures aimed at eliminating the consequences of the unprecedented in the history of mankind Chernobyl disaster [2]. These aspects of the transition period of Ukraine's development have determined the course of modern urbanization.

\section{MATERIALS AND METHODS}

The purpose of the study is to analyze the trends of urban development and transformation of Ukrainian cities in the postChornobyl and post-totalitarian transition period.

In the course of the work a systematic approach, methods of statistical and cartographic analysis were used, namely: the method of interval dynamic series, which is an effective means of assessing phenomena trends and patterns of development in time and space; chamber method, where the map acts as a model of the object under study and an intermediate link in the analysis of the spatial location and dynamics in the space of 'growing cities'.

Cities of Ukraine with a population of over 50 thousand people were selected for analysis; the period from 2001 to 2020 - after the first All-Ukrainian census and the 'abnormal decade' of depopulation due to the accelerated reduction of urban residents (see Fig. 1). The intermediate dates are 2014 and 2018 - the beginning of the Russian military aggression and the fourth year of the invasion.

\section{STARTING POINT}

Urban planning is a continuous and long process, which is conditioned by the transformation of spatial development systemic patterns, changing the spatial development ideology, its socio-economic basis, demographic situation, environmental factors and conditions. Management of this process, first of all, is connected with search of compromises between the purposes of development of ecological and town-planning system "population $\leftrightarrow$ environment" at various stages and its spatial integrity level, and also constant adaptation of this development programs to new specific conditions $[15,16,17]$.

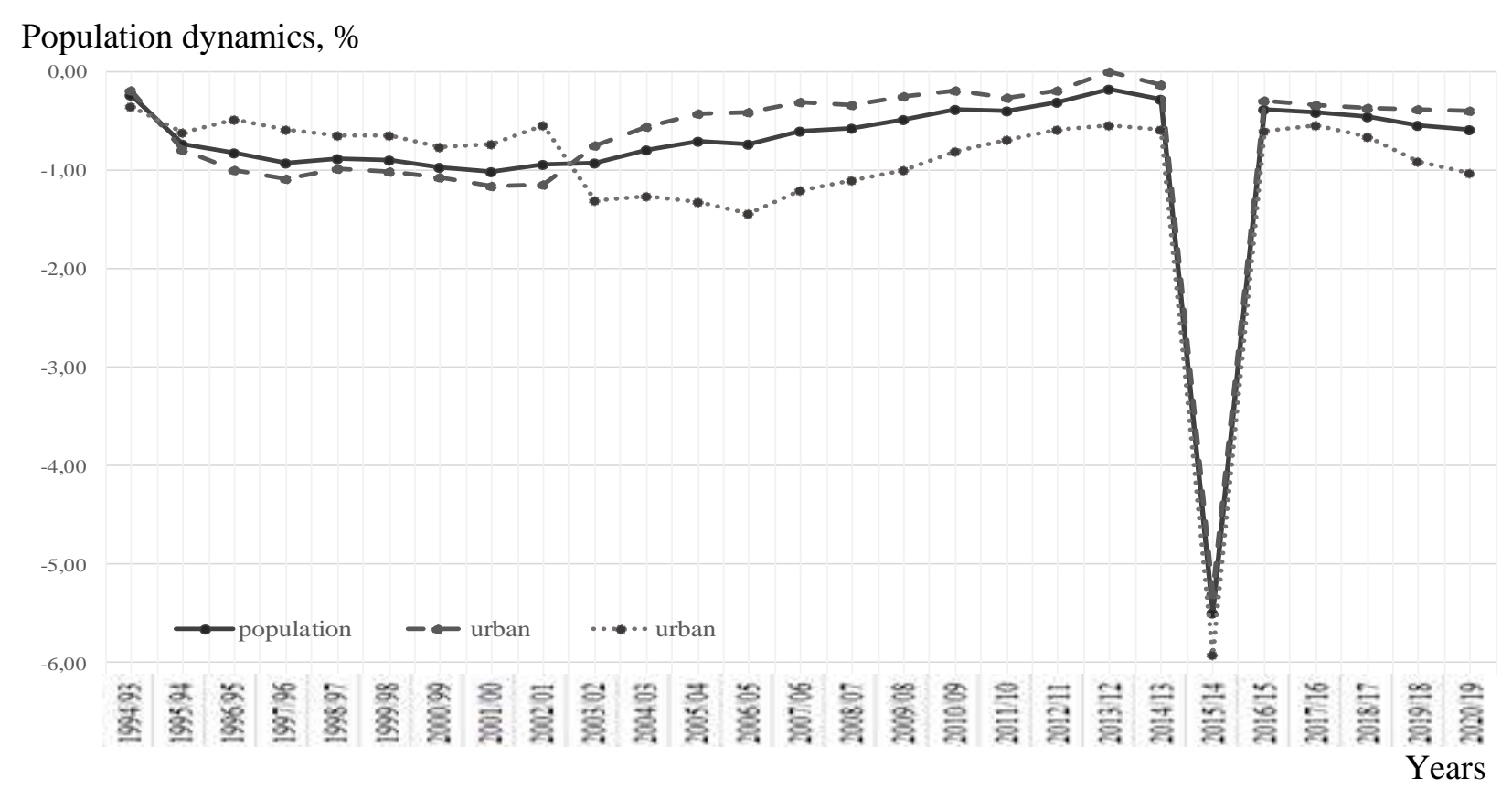

Fig. 1. The average annual population decline in Ukraine during the depopulation period from 1993 to 2020 
There are general trends in urban development in a certain historical epoch [18, 19], but it is possible to identify specific regional features of the post-socialist transition period, which may later be signs of a new 'wave fluctuations' vector of the global urban process [6, $7,20,21,22]$. The relations between society and urbanization in the transition period function in a unique way at the levels of ideology, practice and urban change [23, p. 607].

\section{KYIV NEW GEOPOLITICAL STATUS}

The contemporary Kyiv geopolitical status gives new impacts to Ukraine's movement towards consolidation with the European Community countries, it started in 1995. The new importance of the country in the Pan-European space and its multidisciplinary ties with the countries of Western Europe determines '... the need not only for political and economic integration of all countries of the European continent, but also for spatial planning' [20, p. 107]. In this context, taking into account the geographical location of Ukraine and the area of three-hour accessibility of Kyiv airports, pean countries' planning integration of into a common European territorial structure - the concept of the 'extensive' European space organization in the long run, taking into account the general trends of political and economic process integration' (Fig. 2. b) [20, p. 107].

\section{SOCIO-ECONOMIC AND DEMOGRAPHIC SITUATION}

Regarding the socio-economic development of Ukraine, which is assessed by the UNDP annual reports on the 'human development index' (HDI takes into account the welfare of the population, life expectancy and learning). According to the UNDP Report on the human development for 2019, Ukraine is in the middle of the ranking, it ranks 88th among 189 countries [24, p. 23]. This includes Ukraine in the list of 'human development high category' countries (HDI $=0.75$ [25]), despite the fact that for the period from 1990 to 2018 the welfare of the population, measured by gross national income per capita, decreased by $25.6 \%$ and since 1993 the population has been declining (see Fig. 1) [14].

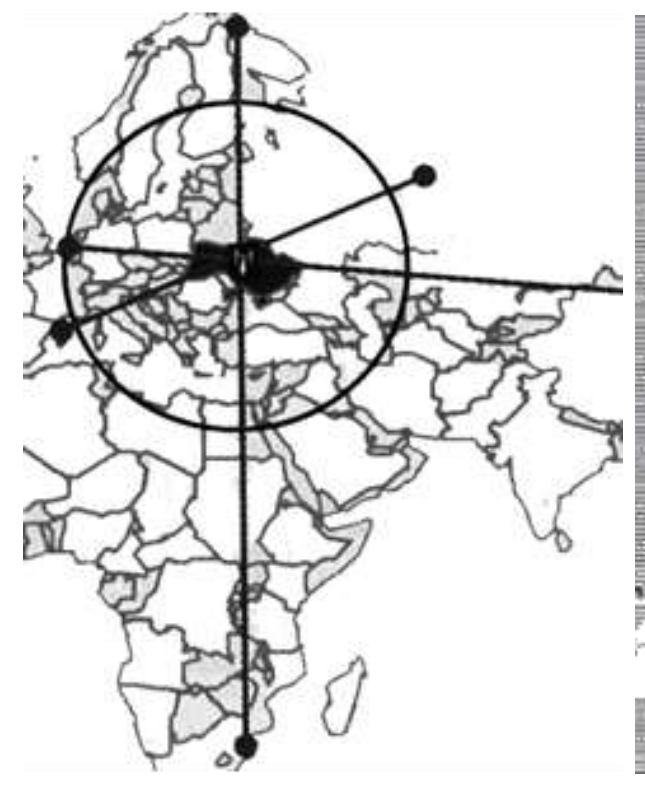

$a$

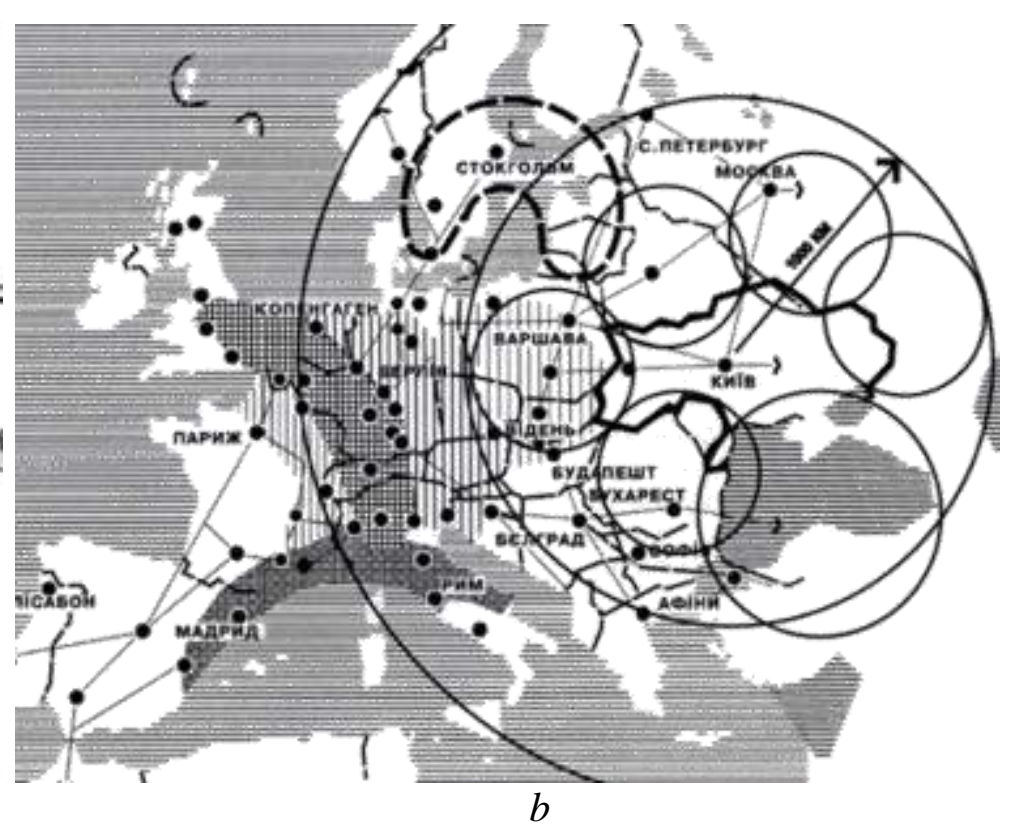

Fig. 2. Kyiv airports three-hour accessibility (a) and the common Pan European planning space area of influence, by Yu. Bilokon (b) covering almost all of Europe and North Africa (Fig. 2. a), the concept of '... Eastern Euro-
That is, despite the socio-economic disturbance and Russia's military aggression, Ukraine 
is showing certain progress in human development. Thus, for the period from 1990 to 2018 , the HDI value increased by $6.4 \%$ (from 0.705 to 0.750 ); birth life expectancy increased by 2.1 years (from 69.9 years in 1990 to 72 years in 2018); the study years average figure -2.2 years, the expected number of years of study -2.7 years [25].

As for the demographic situation (in terms of population reproduction), during the period from 1990 to 2019 (not taking into account temporarily occupied territories data) birth rates in Ukraine decreased (from 12.6 to 8.1; average annual decrease $-1.26 \%$ ) and mortality rates increased from 12.1 to 14.7 , the average annual growth of $0.61 \%$ ), which led to the population negative values acquisition natural growth rates (from +0.5 to -6.6 ) and following 1993 the country's population reduction (see Fig. 1) [14].

During the period of depopulation, which has been burdened by Russian military aggression since 2014 (occupation of the territory of the Autonomous Republic of Crimea and part of the Donbas), the population of Ukraine decreased by $19.7 \%$ (from 52.2 million in 1993 to 41.9 million in 2020 , excluding the temporarily occupied territory of the Autonomous Republic of Crimea; average annual reduction $-0.73 \%$ ). As for the urban population, during this period it decreased more slowly than the total population of Ukraine - by $18 \%$ (from 35.5 million people in 1993 to 29.1 million people in 2020; the average annual decrease $0.67 \%)$ [14].

Comparatively slower decline of the urban population (overall decline of $18<19.7 \%$; average annual decline of $0.67<0.73 \%$ ) indicates an overall increase in the urbanization level in Ukraine. Thus, for the period from 1993 to 2020 it increased by $1.7 \%$ (the share of urban population in $1993-68 \%$, in $2020-69.7 \%$ ) [14].

\section{TRANSITION PERIOD URBANIZATION PROCESSES AS SOCIAL TRANSFORMATION REFLECTION}

Statistical analysis of urban development processes found that in the period from 2001 to 2014 among 89 cities of Ukraine with a population of over 50 thousand people, the population grew only in 15 cities (Table 1) $[26,27]$. In the period under study, among the biggest (over 800 thousand people) and big (over 500 to 800 thousand people) cities of Ukraine [28], only Kyiv grew in number (see Table 1). As for the relatively faster than in Kyiv average annual population growth $(0.76 \%)$ in the cities, it should be noted that the cities of Brovary (1.07\%) and Boryspil $(0.88 \%)$ are part of the Kyiv Agglomeration and they are located in the first belt of Kyiv satellite cities - at a distance of 25 and $39 \mathrm{~km}$, respectively; and Chornomorsk $(0.81 \%)$ is one of the largest seaports in the country.

Cartographic analysis of 'growing cities' spatial location on the map of Ukraine showed the southern, in relation to the Kyiv Agglomeration spatial vector of average annual accelerated urban growth and 'fading power' of growth of the outlying ones from the capital $(1.07 \rightarrow 0.88 \rightarrow 0.81 \%$ ) (Fig. 3.a).

Population dynamics analysis of these cities in the period from 2014 to 2018 showed that among the 15 cities whose population grew in the previous period (see Table 1), only 8 cities in Ukraine continue to grow (no information is available regarding the cities of Sevastopol and Evpatoria,) (Table 2) [26, 27, 29]. The city of Irpin joined the group of growing cities in 2017 (50.4 thousand people [30]).

In the period under review, only Kyiv continues to grow among the big and biggest cities in the country (see Tables 1,2).

Relatively faster than Kyiv $(0.57 \%)$ growth in urban population (see Table 2), in the first zone of the Kyiv Agglomeration the cities of Brovary $(1.24 \%)$ and Boryspil $(0.68 \%)$ continue to grow; the fastest growing city is Irpin $(5.3 \%)$, which is located $26 \mathrm{~km}$ from Kyiv, may be added to them (see Table 2).

In the period under review, compared to the previous period (see Tables 2 and 1), the growth of the city of Ivano-Frankivsk accelerated almost threefold $(0.31 \rightarrow 0.92 \%)$. This 'turned' the country spatial vector of the growing cities location from south to southwest (Fig. 3.b). 
Table 1. Growing cities of Ukraine with a population of over 50 thousand people in the period from 2001 to 2014

\begin{tabular}{|l|l|c|c|c|}
\hline \multirow{2}{*}{ City } & \multicolumn{2}{|c|}{ Number of available population (people) } & \multirow{2}{*}{$\begin{array}{c}\text { Average annual popu- } \\
\text { lation growth, (\%) }\end{array}$} \\
\cline { 3 - 5 } & & $2001^{1}$ & 2014 & $\mathbf{0 , 7 6}$ \\
\hline 1. & Kyiv & 2611327 & 2868702 & 0,05 \\
\hline 2. & Sevastopol & 342451 & 344853 & 0,37 \\
\hline 3. & Khmelnitskyi & 253994 & 266095 & 0,03 \\
\hline 4. & Rivne & 248813 & 249912 & 0,31 \\
\hline 5. & Ivano-Frankivsk & 218359 & 227030 & 0,27 \\
\hline 6. & Lutsk & 208816 & 216076 & 0,04 \\
\hline 7. & Bila Tserkva & 210128 & 211205 & 0,08 \\
\hline 8. & Evpatoria & 105915 & 107040 & 0,20 \\
\hline 9. & Kamyanets Podilskyi & 99610 & 102254 & $\mathbf{1 , 0 7}$ \\
\hline 10. & Brovary & 86839 & 98874 & 0,29 \\
\hline 11. & Mukacheve & 82346 & 85487 & 0,30 \\
\hline 12. & Kovel & 66401 & 69032 & $\mathbf{0 , 8 8}$ \\
\hline 13. & Boryspil & 53975 & 60160 & $\mathbf{0 , 8 1}$ \\
\hline 14. & Chornomorsk & 54151 & 59840 & 0,03 \\
\hline 15. & Horishni Plavni & 51740 & 51958 & 0,65 \\
\hline 16. & Irpin ${ }^{2}$ & 40593 & 44023 & \\
\hline
\end{tabular}

Notes:

1. according to the All-Ukrainian census of December 5, 2001

2. to be included in the group of cities under study in 2017

Table 2. Growing cities of Ukraine with a population of over 50 thousand people in the period from 2014 to 2018 (no information available on the cities of the Autonomous Republic of Crimea)

\begin{tabular}{|l|l|c|c|c|}
\hline \multirow{2}{*}{ City } & \multicolumn{2}{|c|}{ Number of available population (people) } & \multirow{2}{*}{$\begin{array}{c}\text { Average annual popula- } \\
\text { tion growth, (\%) }\end{array}$} \\
\cline { 3 - 5 } & & 2014 & 2018 & $\mathbf{0 , 5 7}$ \\
\hline 1. & Kyiv & 2868702 & 2934522 & 0,22 \\
\hline 2. & Khmelnitskyi & 266095 & 268417 & $\mathbf{0 , 9 2}$ \\
\hline 3. & Ivano-Frankivsk & 227030 & 237686 & 0,05 \\
\hline 4. & Lutsk & 216076 & 216505 & $\mathbf{1 , 2 4}$ \\
\hline 5. & Brovary & 98874 & 103787 & 0,12 \\
\hline 6. & Mukacheve & 85487 & 85796 & 0,02 \\
\hline 7. & Kovel & 69032 & 69089 & $\mathbf{0 , 6 8}$ \\
\hline 8. & Boryspil & 60160 & 61807 & $\mathbf{5 , 3}$ \\
\hline 9. & Irpin & 44023 & $\mathbf{5 3 3 6 1}$ & \\
\hline
\end{tabular}




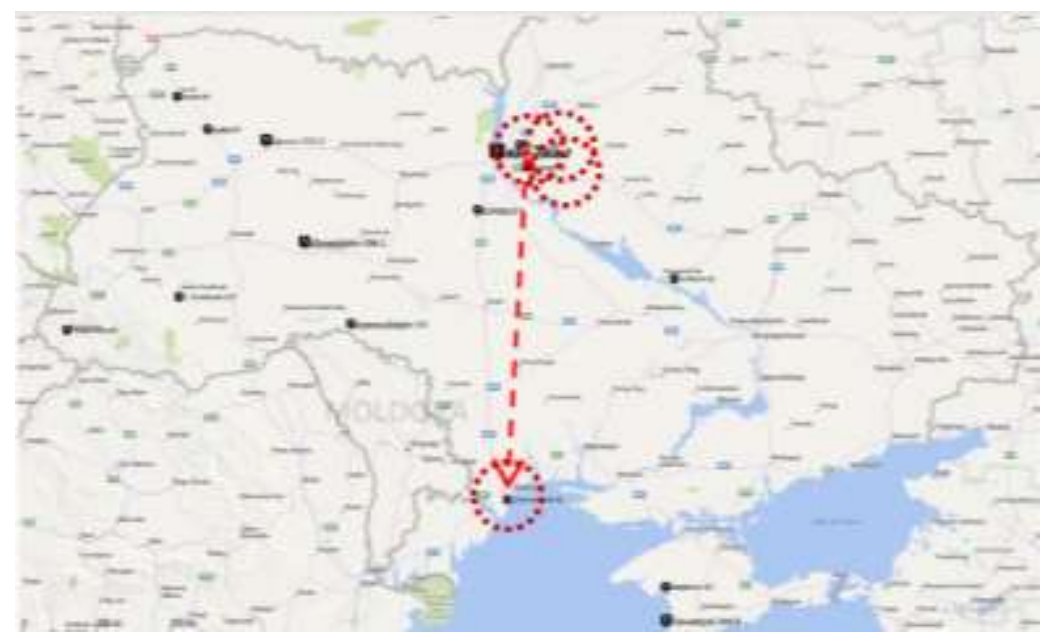

a. $2001-2014$

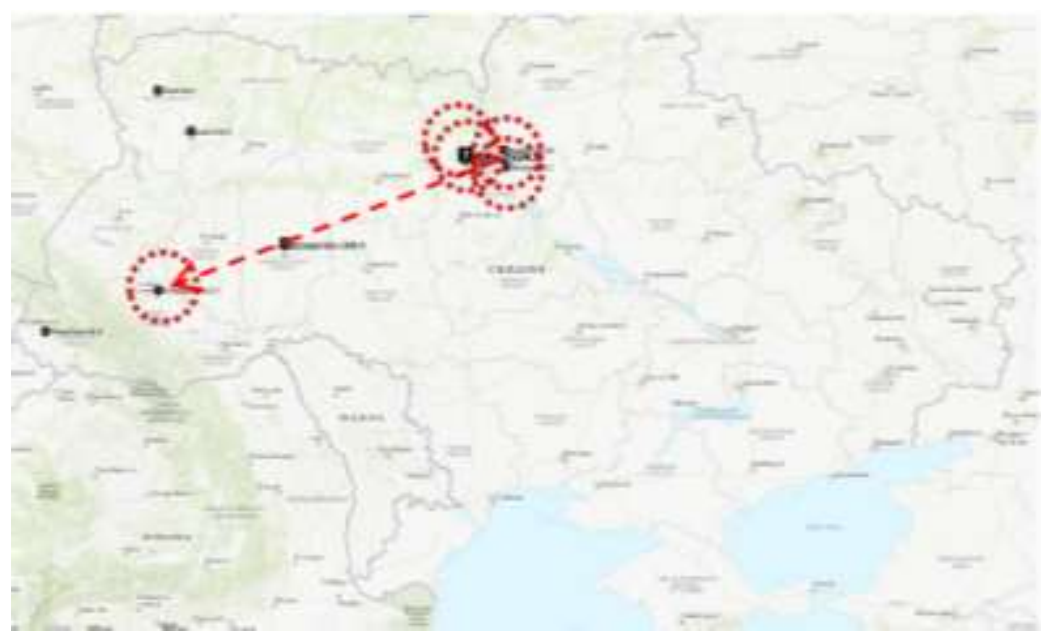

b. $2014-2018$

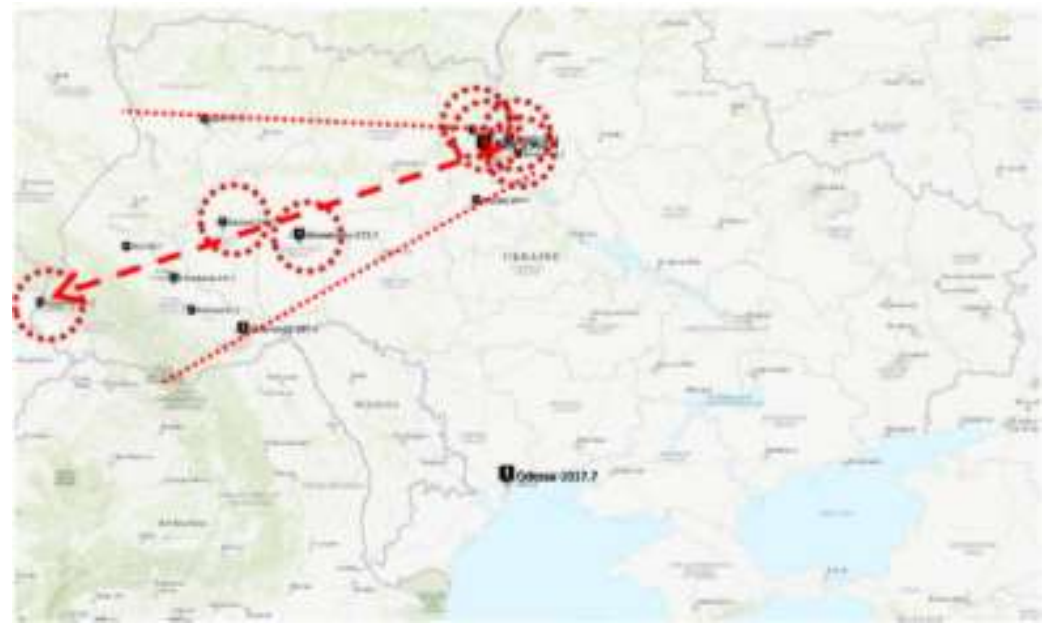

c. $2018-2020$

Chornobyl NPP Exclusion zone

- Cities with growing populations

growing faster than Kyiv

--- Spatial vector and Urbanization process spatial sector

Fig. 3. Cities of Ukraine with a population of over 50 thousand people where the number increased in the period from 2001 to 2020 
The analysis of the cities' population dynamics in the period from 2018 to 2020 showed that in the trend of 8 cities, the population of which has been growing since 2001 (see Tables 1,2 ), there are only 6 left, these are Kyiv, Khmelnytskyi, Ivano-Frankivsk, Lutsk, Brovary and Boryspil; The city of Bila Tserkva renewed its growing (see Table 1) and 6 'new growing cities' were added: Odessa, Chernivtsi, Ternopil, Uzhhorod, Kolomyia, and Stryi (Table 3) [29].

It should be noted that in the period under review, the second largest growing city of Odessa appeared for the first time (over 800 thousand people); among the growing big cities - Chernivtsi (over 250 to 500 thousand people), among the medium - Ternopil, Uzhgorod, Kolomyia and Stryi (over 50 to 250 thousand people) [28] (see Table 3).

The appearance of the second biggest city of Odessa, growing after Kyiv, testifies to certain 'spatial alignment' of the country's urban development potentials along the North-South axis (Fig. 3. c).

As is known, at the end of the 19th - beginning of the 20th century, Odessa was significantly ahead of Kyiv development in its dynamics, because then its industrial and demographic potential significantly exceeded the potential of Kyiv [19].

The emergence of five 'new growing cities' in Western Ukraine (Chernivtsi, Ternopil, Uzhhorod, Kolomyia, Stryi) in addition to the three cities that have been growing since 2001 (Khmelnytskyi, Ivano-Frankivsk, Lutsk) has significantly strengthened the south-western 'urbanization spatial vector process', which was faster than of Kyiv $(0.56 \%)$; growth of Ternopil (1.1\%), Khmelnytskyi (0.99\%), Uzhgorod $(0.66 \%)$ and the 'western spatial sector' formation of the growing cities of Ukraine with a population of over 50 thousand people (see Fig. 3.c).

Relatively faster than Kyiv $(0.56 \%)$ average annual population is the growth in the cities of the Kyiv Agglomeration. In the first zone, the cities of Irpin (6.3\%), Brovary (2.2\%) and Boryspil $(1.1 \%)$ continue to grow steadily. In addition, in the second belt of satellite cities, the city of Bila Tserkva $(0.01 \%)$, located at a distance of $89 \mathrm{~km}$ from Kyiv, began to grow again (see Fig. 3. a, c).

The specifics of Kyiv Agglomeration first belt urban growth. In the near zone of Kyiv influence (up to $40 \mathrm{~km}$ ) the 'gravitational tendency' continues to gain momentum of [31] acceleration the average annual population growth of the cities of Irpin $(0.65 \rightarrow 5.3 \rightarrow$

Table 3. Growing cities of Ukraine with a population of over 50 thousand people in the period from 2018 to 2020

\begin{tabular}{|l|l|c|c|c|}
\hline \multirow{2}{*}{ City } & \multicolumn{2}{|c|}{ Number of available population (people) } & \multirow{2}{*}{$\begin{array}{c}\text { Average annual popu- } \\
\text { lation growth, (\%) }\end{array}$} \\
\cline { 3 - 4 } & & 2018 & 2020 & $\mathbf{0 , 5 6}$ \\
\hline 1. & Kyiv & 2934522 & 2967360 & 0,31 \\
\hline 2. & Odessa & 1011494 & 1017699 & $\mathbf{0 , 9 9}$ \\
\hline 3. & Khmelnytskyi & 268417 & 273713 & 0,26 \\
\hline 4. & Chernivtsi & 265682 & 267060 & 0,50 \\
\hline 5. & Ivano-Frankivsk & 235355 & 237686 & $\mathbf{1 , 1 0}$ \\
\hline 6. & Ternopil & 218653 & 223462 & 0,19 \\
\hline 7. & Lutsk & 216505 & 217315 & 0,01 \\
\hline 8. & Bila Tserkva & 209176 & 209238 & $\mathbf{0 , 6 6}$ \\
\hline 9. & Uzhorod & 113996 & 115512 & $\mathbf{2 , 2 0}$ \\
\hline 10. & Brovary & 103787 & 108349 & $\mathbf{1 , 1 0}$ \\
\hline 11. & Boryspil & 61807 & 63169 & 0,22 \\
\hline 12. & Kolomiya & 60993 & 61265 & 0,53 \\
\hline 13. & Stryi & 59099 & 59730 & $\mathbf{6 , 3 0}$ \\
\hline 14. & Irpin & 53361 & 60084 & \\
\hline
\end{tabular}


$6.3 \%)$, Brovary $(1.07 \rightarrow 1.24 \rightarrow 2.2 \%)$ and Boryspil $(0.88 \rightarrow 0.68 \rightarrow 1.1 \%)$, which are located at a distance of 26,25 and $39 \mathrm{~km}$ from Kyiv, respectively.

The accelerated growth of these satellite cities is due to the availability of jobs in the capital and lower housing costs in its suburbs. The reverse side of the 'first zone overheating' is the Kyiv Agglomeration core 'cooling', which is manifested by a 'reversible slowdown' of the average annual population growth of Kyiv $(0.76 \rightarrow 0.57 \rightarrow 0.56 \%)$ (see table. $1,2,3$, Fig. 3) $[21,22]$.

This is a manifestation of the general 'gravitational pattern' of space development [31], which is manifested in the territorial inequality of economic development of countries, and regions, disparities in income and living standards. As noted in the World Bank's 2009 World Development Report, prosperity leads to the economy 'oversaturation'; as a result of which there is an economic activity 'overflow', but only in those areas that are closely associated with prosperous areas' [32, p. 16].

This causes business activity 'overflow' from the biggest cities to the space of urban agglomerations, which in turn leads to cyclical spatial development: alternating transition from centralized to decentralized forms of settlement and the emergence of 'gravitational waves' that circularly spread from urban cities to the peripheral urban areas [31].

Both these tendencies of contemporary urban development in the near zone of Kyiv influence demonstrate this, as well as the emergence of the 'western urbanization spatial sector process' from the eight growing cities of the country in Volyn, Lviv, Ternopil, Khmelnytskyi, Ivano-Frankivsk, Zakarpattia and Chernivtsi that are in the near area of the European Union influence (see Fig. 3.c).

No doubt, these processes are a manifestation of the post-totalitarian transformation of the urbanization space of Ukraine, a projection of social transformation and the reaction of this space to the Russian military aggression in the East of the country with the annexation of the Autonomous Republic of Crimea. The strengthening of the south-western 'spatial vector' and the emergence of the western 'spa- tial sector' of the urbanization process (see Fig. 3) may indicate the 'memory of spatial structures', the presence of which allows to interpret post-socialist transformations as 'return to pre-socialist development trajectories' [33, p. 558; 15] of Ukraine in a common European political, economic and planning space (see Fig. 2).

The western region of Ukraine is bordering the European Union (Poland, Slovakia, Hungary, Romania), whose development is supported by the EU's spatial policy, including the new philosophy of governance [34], which directly relate to the development of metropolises and the metropolisation process [35].

In the context of balancing spatial potentials and adaptive management of sustainable development of territories, the experience of metropolisation can be useful in the posttotalitarian transition period of Ukrainian cities development.

\section{METROPOLIS ESTABLISHMENT AND TRANSFORMATION OF HISTORI- CAL CITIES}

The international significance and metropolitan functions concentration (organization and management, economic, informationrepresentative, cultural, innovation-creative, transport and communication, social) gives cities the status of a metropolis. These cities are the 'poles of growth', on which depends the development of the surrounding area [35, p. 34 $-35]$.

According to research, the assessment of the implementation level of these functions in the cities - regional centers of Ukraine for 2005-2014 showed that Kyiv falls under the status of a regional metropolis in the European metropolitan network (see Fig. 2), and Kharkiv, Odessa, Dnipro, Donetsk and Lviv under the status of regional metropolises as part of the national metropolitan network. The specialization of the Donetsk metropolitan functions development (until 2014) was administrative and economic; Dnipro - investment and economic; Kharkiv - educationalscientific, innovative; Odessa - political, lo- 
gistical, cultural and tourist; Lviv - political, transport, cultural and tourist [35, p. 456].

As for the development of metropolitan functions in Western Ukraine regional centers, their potential is enhanced by the emergence of new types of economic activity. Realization of their potential, taking into account the features of these cities (Lutsk - mechanical engineering; Rivne - mechanical engineering, manufacturing; Uzhgorod - mechanical engineering, logistics; Ternopil - educational center, agro-industrial complex; Chernivtsi - educational center, trade; Ivano-Frankivsk - educational center, mining industry), will contribute to the inflow of additional resources (human, financial, material) [35, p. 34-36].

The effect of metropolization global processes in the post-totalitarian transition period of development of Ukrainian cities was revealed by our research (see Fig. 3).

The transformation of historical cities, the 'crossroads of civilizations' [34]. Now these cities face the dilemma of preserving the existing 'spatial-planning environment' and the need for further active use of historical and cultural potential. In historical cities monuments of different eras and styles are closely situated, coordinated and coexist, the appearance of cities reflects the patterns of the past and present. The main criterion for the transformation of such cities in modern conditions is their architectural and artistic succession and an acceptable level of reconstruction.

Cultural and architectural monuments should not be exclusively museum exhibits in the authentic environment of the historic city. They must be adapted to contemporary needs, which can be one of the radical ways to preserve them. Creative searches of Ukrainian architects in the field of reconstruction of historic cities, in particular in recent years, present a wide range of using the heritage of historic cities for various functions: cultural and educational (cinemas, exhibitions, libraries, educational centers); museum (city history museums; lifestyle museums); travelling (historical and architectural reserves, tourist services, hotels) [4].

The global attractiveness of Chornobyl tourism; the main task of which is the aware- ness of humanity of the nuclear catastrophe scale and its environmental and humanitarian consequences. It should be noted that the natural and architectural-landscape heritage of the exclusion zone can become an independent unique object of cultural-cognitive, research, educational-ecological, sentimental and religious (since the $18^{\text {th }}$ century Chornobyl was one of the Hasidism centers in Ukraine) tourism $[2,4]$.

\section{CONCLUSIONS}

1. Despite the socio-economic disturbance in the post-totalitarian transition period and Russia's military aggression, according to UNDP, Ukraine is among the 'human development high category' countries and it shows certain progress in this direction. Thus, during the period from 1990 to 2018, the human development index value increased by $6.4 \%$ (from 0.705 to 0.750 ).

2. Along with the population decline in Ukraine, the level of country urbanization continues to grow. Thus, during the period of depopulation - from 1993 to 2020 the population decreased by $19.7 \%$ (from 52.2 to 41.9 million people, excluding the temporarily occupied territory of the Autonomous Republic of Crimea), and the share of urban population increased by $1,7 \%$ (from 68 to $69.7 \%$ ), which is the evidence of cities 'gravitational influence' increase.

3. During the transitional period of development of Ukrainian cities there is a balancing of spatial development potentials of Ukraine. This is evidenced by the appearance in the south of the country following 2018 the second largest growing city after Kyiv - Odessa, and in the west - five growing cities with a population of over 50 thousand people (Chernivtsi, Ternopil, Uzhgorod, Kolomyia, Stryi), in addition to three cities that were growing after 2001 (Khmelnytskyi, Ivano-Frankivsk, Lutsk). This may help to renew the urbanization process along the North-South axis and strengthen its role in the 'western spatial sector' of the growing cities in Ukraine, which are the nearest to the European Union border. 
4. The appearance of Kyiv - Odessa Meridional axis, the south-west 'urbanization process spatial vector', which turned out to be swifter than the Kyiv growth, with the cities of Ternopil, Khmelnytskyi, Uzhhorod and the strengthening of the 'west urbanization process spatial sector', may indicate: first, the 'memory of spatial structures', the existence of which allows us to interpret post-socialist transformations as a 'return to the pre-socialist development trajectory' of the country in a common Pan-European space; secondly, the cyclical development and movement reversibility in the 'urban process world waves'; third, the 'reaction of the urbanization space' of Ukraine to the Russian military aggression in the East of the country with the annexation of the Autonomous Republic of Crimea and part of the Donbas territories.

5. The features of the Kyiv Agglomeration post-socialist development reflect the new status of Kyiv as a regional metropolis in the European metropolitan network, and the general 'gravitational pattern' of spatial development, which is manifested in territorial inequality of economic development and 'pole growth migration'. This manifest itself in the acceleration of the average annual population growth of the cities of Irpin, Brovary and Boryspil, which are located in the Kyiv nearest area of influence (up to $40 \mathrm{~km}$ ), and the reversible slowdown in the average annual population growth in Kyiv.

6. The post-Chornobyl growth of the Chornobyl Exclusion Zone attractiveness, where $80 \%$ of visitors are citizens from 130 countries, will contribute to the further transformation of Ukrainian cities. In particular, airway connection will positively influence the development of Kyiv and the Kyiv Agglomeration; road connection - development of west and south border cities, as well as cities in the area of influence of Pan-European transport corridors №3, №5 and №9; railway connection - development of Kyiv, Chernihiv and Slavutych; implementation of the Dnipro-Visla waterway E40 Project, the purpose of which is to connect the Baltic and Black Seas - the development of river ports on the Dnipro and Pripyat Rivers, namely: Kherson, Nova
Kakhovka, Nikopol, Zaporizhya, Dnipro, Kamyanske, Kremenchuk, Cherkasy, Kyiv and Chernobyl.

\section{REFERENCES}

1. Law of Ukraine On the legal regime of the territory suffered from radioactive contamination as a result of the Chornobyl disaster. No.795XII, VVR, 1991, No.16, 199. https://zakon.rada.gov.ua/laws/show/791\%D0\% B0-12 (in Ukrainian).

2. Ustinova I.I, Dyomin M.M, Aylikova G.V, 2020. Reintegration of the Chornobyl NPP Exclusion Zone on the basis of the designplanning complex. Ukrainian Geographical Journal, Vol. 04 (112), 11-18. DOI: https://doi.org/10.15407/ugz2020.04.011 (in Ukrainian).

3. In 2019, 124 thousand people visited the Chornobyl Exclusion Zone (Official Website of the State Enterprise "Center for Organizational, Technical and Information Support of the Exclusion Zone Management"). Received from: https://cotiz.org.ua/novyny/2019 (in Ukrainian).

4. Tamara Panchenko, Mykhailo Sukach, Andriy Golub, 2018. Sustainable Tourism Development in Ukraine. Transfer of Innovative Technologies, Vol.1, No.2, 3-20. https://doi.org/10.31493/tit1812.0101.

5. Thomas Borén \& Michael Gentile, 2016. Metropolitan processes in post-communist states: an introduction.

Geographic Annaler: Series B Human Geography, Vol.89, 95-110. https://doi.org/10.1111/j.14680467.2007.00242.x

6. Eurasian Geography and Economics, 2016. Post-Socialist Cities and Urban Theory. Vol.57, Iss.4-5. https://www.tandfonline.com/toc/rege 20/57/4-5 ?nav=tocList\&.

7. K.V. Mezentsev, O.O. Denysenko, 2018. Cities in post-socialist space: approaches to conceptualization and placing in urban discourse. Ukrainian Geographical Journal, Vol.4, 16-24. https://doi.org/10.15407/ugz2018.04.016 (in Ukrainian).

8. Population (estimated) on April 1, 2021 and the average population in January-March 2021. State Statistics Service of Ukraine, M.V. Ptukha Institute of Demography and Social Research of the National Academy of Sciences of Ukraine, Received from: http://database.ukrcensus.gov. ua/PXWEB2007/ukr/news/op_popul.asp (in Ukrainian). 
9. European countries by population on January 1, 2020. Received from: https://ru.wikipedia.org/wiki/ (in Russian).

10. List of European countries by area. Received from: https://uk.wikipedia.org/wiki/ (in Ukrainian).

11. Stefan Bouzarovski, Luděk Sýkora \& Roman Matoušek, 2016. Locked-in postsocialism: rolling path dependencies in Liberec's district heating system. Eurasian Geography and Economics, Vol.57, Iss.4-5, 624-642. https:// doi.org/10.1080/15387216.2016. 1250224.

12. Sosnova N.S., 2021. Theoretic and Methodological Bases of Formation of Public Spaces of Ukrainian Cities. Abstract of a Thesis on Achieving of Degree of Doctor in Architectural Sciences, Spec. 18.00.01 Theory of Architecture, Restoration of Architectural Monuments. Lviv, 44 (in Ukrainian).

13. Kondel-Perminova N., 2012. The Problems of a Post-Soviet City Interview with Volodymyr Nudelman and Henrich Filvarov. Urban Studies. An Anatomy of a City: Kyiv. Kyiv, 67-75 (in Ukrainian).

14. Population 1990-2020. State Statistics Service of Ukraine. Date of the last modification: 30.06.2020. Received from: http://ukrstat.gov.ua/operativ/operativ2007/ds/n as_rik/nas_u/nas_rik_u.html (in Ukrainian).

15. Dyomin N.M., 1991. Management by development of town-planning systems. Kyiv, Budivelnik, 185 (in Russian).

16. Town-planning. Reference book for the designer, 2006. Second Edition (ed. T.F. Panchenko). Kyiv, UkrArchBudInform, 192 (in Ukrainian).

17. Ustinova I.I., 2016. The Methodological Foundations of Sustainable Development of Ecological and City-Planning Systems. Abstract of a Thesis on Achieving of Degree of Doctor in Architectural Sciences, Spec. 18.00.01 Theory of Architecture, Restoration of Architectural Monuments. Kyiv, 46 (in Ukrainian).

18. Forrester. J., 1974. Dynamics of city development. Moscow, 286 (in Russian).

19. Pleshkanovska A.M., Savchenko O.D., 2019. Epochs and cities. Kyiv, 264 (in Ukrainian).

20. Bilokon Y.M., 2003. Regional planning (theory and practice). Kyiv, 246 (in Ukrainian).

21. Iryna Ustinova, 2015. Theoretical principles of wave urbanistics, Underwater Technologies, Iss.01, 33-42.

22. Iryna Ustinova, 2018. Urban planning aspects of stability theory of ecological town planning systems. Transfer of Innovative Technologies, Vol.01, No.1, 5-16. https://doi.org/10.31493/ tit1811.0101

23. Oleg Golubchikov, 2016. The urbanization of transition: ideology and the urban experience. Eurasian Geography and Economics, Vol.57, Iss. 4-5, 607-623. https://doi.org/10.1080/ 15387216.2016.1248461.

24. Overview Human Development Report 2019. Beyond income, beyond averages, beyond today: Inequalities in human development in the 21st century. Published for the United Nations Development Program (UNDP), NY 10017 USA, 28. Received from: http://hdr.undp.org/sites/default/files/hdr_2019 overview_-_english.pdf.

25. Report on the state of human development for 2019: Overview. Analytical note "Ukraine" Received from: https://www.ua.undp.org/ content/ukraine/uk/home/presscenter/ pressreleases/2019/ukraine-ranks-mid-table-inundps-2019-human-development-report.htmlT (in Ukrainian).

26. Cities of Ukraine by population. Received from: https://uk.wikipedia.org/wiki/wiki/ (in Ukrainian).

27. The current population of Ukraine as of January 1, 2014. State Statistics Service of Ukraine. Statistical collection. Kyiv, 112 (in Ukrainian).

28. DBN B.2.2-12:2019, 2019. Planning and territories' development. Kyiv, Ministry of Regional Development of Ukraine, 177 (in Ukrainian).

29. The current population of Ukraine as of January 1, 2020. State Statistics Service of Ukraine. Statistical collection. Kyiv, 82 (in Ukrainian).

30. Cities \& towns of Ukraine Received from: http://pop-stat.mashke.org/ukraine-cities.htm (http://pop-stat.mashke.org/ Statistics of the population of Eastern Europe and the former USSR) (in Ukraine).

31. Ustinova I.I., 2017. Gravitational processes in the ecological space of urbanization. Problems of theory and history of architecture of Ukraine. Odessa, Vol.17, 23-30 (in Ukrainian).

32. World Development Report, 2009. A New Look at Economic Geography [Review]. World Bank, Washington, 48 (in Russian).

33. Liviu Chelcea \& Oana Druţă, 2016. Zombie socialism and the rise of neoliberalism in postsocialist Central and Eastern Europe. Eurasian Geography and Economics, Vol.57, Iss.4-5, 521-544. https://doi.org/10.1080/15387216. 2016.1266273. 
34. European Charter of Cities - II: Manifesto of New Urbanism, 2008. Academy of Public Participation, 13. http://www.slg-coe.org.ua/ wp-content/uploads/2015/05/Principle-9. European-chart.pdf (in Ukrainian).

35. Metropolitan functions of big cities of Ukraine: development potential and prospects for implementation, 2016. Scient. ed. M. Melnyk Lviv, E. Dolishny State Institution "Institute of Regional Studies. NAS of Ukraine», 552 (in Ukrainian).

\section{Трансформация украинских городов в пост- Чернобыльский и пост-тоталитарный «переходный» период}

\section{Николай Дёмин, Тамара Панченко, Ирина Устинова}

Аннотация. Исследованием трансформации украинских городов в пост-Чернобыльский и пост-тоталитарный переходный период выявлен ряд общих тенденций развития и региональные особенности мирового урбанистического процесса. Несмотря на социальноэкономические потрясения, вооруженную агрессию России и сокращение численности населения, Украина вошла в перечень стран «высокой категории человеческого развития».

Исследования показали, что уровень урбанизации в стране продолжает расти, при этом происходит балансировка потенциалов ее пространственного развития. О чем свидетельствует появление «меридиональной оси», «югозападного пространственного вектора» и «западного сектора» развития урбанизационного процесса в Украине.

Отмеченное может указывать, во-первых, на «память пространственных структур», наличие которых позволяет интерпретировать постсоциалистические трансформации как «возвращение к досоциалистическим траекториям развития» Украины в едином Пан-Европейском пространстве; во-вторых, о цикличности развития и реверсивности «колебательного движения волн» урбанистического процесса; в-третьих, о «реакции урбанизированного пространства» страны на российскую вооруженную агрессию на востоке Украины с оккупацией АР Крым и части территорий Донбасса.
Специфика постсоциалистического развития Киевской Агломерации отражает новый статус Киева и общую тенденцию развития европейской метрополитарной сети, а также «гравитационную закономерность» освоения пространства, которая проявляется территориальной неравномерностью экономического развития и «волновой миграцией полюсов роста» от центра к периферии и обратно.

Пост-чернобыльский рост туристической атрактивности Чернобыльской зоны отчуждения, $80 \%$ посетителей которой иностранцы, может содействовать дальнейшей трансформации украинских городов. В частности, авиасообщение - развитию Киева и Киевской Агломерации; автомобильное - развитию приграничных городов запада и юга страны, а также городов в зонах влияния Пан-Европейских транспортных коридоров; железнодорожное развитию Киева, Чернигова, Славутича; реализация проекта Днепровско-Вислянского водного пути, назначением которого является соединение Балтийского и Черного морей - развитию городов-речных портов вдоль рек Днепр и Припять.

Ключевые слова: урбанистические процессы, эколого-градостроительные системы, города, системы расселения, пост-тоталитарный период, зона отчуждения Чернобыльской АЭС. 